\title{
Summary of Previous Chamber or Controlled Anthrax Studies and Recommendations for Possible Additional Studies
}
G.F. Piepel ${ }^{\star}$
B.G. Amidan*
J.B. Morrow**

*Pacific Northwest National Laboratory, Richland, Washington

${ }^{* *}$ National Institute of Standards and Technology, Gaithersburg, Maryland

December 2010

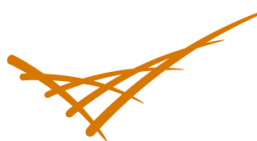

Pacific Northwest NATIONAL LABORATORY 


\title{
DISCLAIMER
}

This report was prepared as an account of work sponsored by an agency of the United States Government. Neither the United States Government nor any agency thereof, nor Battelle Memorial Institute, nor any of their employees, makes any warranty, express or implied, or assumes any legal liability or responsibility for the accuracy, completeness, or usefulness of any information, apparatus, product, or process disclosed, or represents that its use would not infringe privately owned rights. Reference herein to any specific commercial product, process, or service by trade name, trademark, manufacturer, or otherwise does not necessarily constitute or imply its endorsement, recommendation, or favoring by the United States Government or any agency thereof, or Battelle Memorial Institute. The views and opinions of authors expressed herein do not necessarily state or reflect those of the United States Government or any agency thereof.

\author{
PACIFIC NORTHWEST NATIONAL LABORATORY \\ operated by \\ BATTELLE \\ for the \\ UNITED STATES DEPARTMENT OF ENERGY \\ under Contract DE-ACO5-76RL01830
}

Printed in the United States of America
Available to DOE and DOE contractors from the
Office of Scientific and Technical Information,
P.O. Box 62, Oak Ridge, TN 37831-0062;
ph: (865) 576-8401
fax: $(865) 5765728$
email: reports@adonis.osti.gov

\author{
Available to the public from the National Technical Information Service, \\ U.S. Department of Commerce, 5285 Port Royal Rd., Springfield, VA 22161 \\ ph: (800) 553-6847$$
\text { fax: (703) 605-6900 }
$$ \\ email: orders@nits.fedworld.gov \\ online ordering: http://www.ntis.gov/ordering.htm
}




\section{Summary of Previous Chamber or Controlled Anthrax Studies and Recommendations for Possible Additional Studies}

G.F. Piepel*

B.G. Amidan*

J.B. Morrow**

*Pacific Northwest National Laboratory, Richland, Washington

** National Institute of Standards and Technology, Gaithersburg, Maryland

December 2010, Rev. 1

November 2009, Rev. 0

Prepared for

the U.S. Department of Energy

under Contract DE-AC05-76RL01830

Pacific Northwest National Laboratory

Richland, Washington 99352 


\section{Introduction}

This report and an associated Excel file ${ }^{(a)}$ summarizes the investigations and results of previous chamber and controlled studies ${ }^{(b)}$ to characterize the performance of methods for collecting, storing and/or transporting, extracting, and analyzing samples from surfaces contaminated by Bacillus anthracis (BA) or related simulants. This report and the Excel are the joint work of the Pacific Northwest National Laboratory (PNNL) and the National Institute of Standards and Technology (NIST) for the Department of Homeland Security, Science and Technology Directorate. The report was originally released as PNNL-SA-69338, Rev. 0 in November 2009 with limited distribution, but was subsequently cleared for release with unlimited distribution in this Rev. 1. Only minor changes were made to Rev. 0 to yield Rev. 1 . A more substantial update (including summarizing data from other studies and more condensed summary tables of data) is underway

The focus in this report is on (1) samples collected by swab, wipe, and vacuum methods, and (2) cultured and counted results. The summary of previous studies shows significant gaps in the performance information. Hence, we discuss recommendations and options for one or more future chamber or controlled studies that would be performed under the Validated Sampling Plan Working Group (VSPWG).

To address GAO and Congressional concerns following the anthrax letter attacks in 2001, one of the VSPWG's goals is to validate methods for collecting, storing/transporting, preparing/extracting, and analyzing samples from buildings contaminated by BA. One step of the process to validate a method is to "characterize the method", which can consist of several actions (Piepel and Amidan 2009). Two of these actions include quantifying (1) the uncertainty (repeatability and reproducibility) and accuracy of results obtained by the method and (2) relevant performance metrics [e.g., limit of detection (LOD), recovery efficiency (RE), false negative rate (FNR), and false positive rate (FPR)]. Hence, the summary of previous chamber and controlled studies contained in this report includes estimates of uncertainties and several performance metrics, when available in the article or technical report documenting a particular study.

In response to the GAO and Congressional concerns, the other main goal of the VSPWG is to develop sampling strategies, approaches, and methods that will provide high confidence in the ability to characterize the extent of building contamination by BA and the effectiveness of decontamination procedures applied to a contaminated facility. Sampling approaches examined by the VSPWG included judgmental and probabilistic (statistical) sampling, as well as hybrids of the two approaches (Amidan et al. 2007, Piepel et al. 2009). These investigations provide a basis for specifying the roles of the different sampling approaches in a comprehensive sampling

\footnotetext{
(a) This report and Excel file ["Summary of Anthrax Chamber and Controlled Studies, PNL-SA-69338 (PNNL 200911-04).xls"] have been reviewed by an Authorized Derivative Classifier, rated "Unclassified". They were cleared by for unlimited release.

(b) In this report, a "chamber study" refers to a study in an enclosed chamber. A "controlled study" refers to a study in which contaminant concentrations on surfaces and reference samples are highly controlled so as to provide a defensible basis for "actual" contamination and calculating recovery efficiencies. Such studies may utilize a larger space. Or, they may investigate only part of the sampling process, and may not involve the sampling step in a physical space.
} 
strategy $^{(\text {a) }}$. Probabilistic and hybrid sampling approaches provide a formal statistical and mathematical structure for determining the number of samples necessary to provide the desired confidence levels for (1) detecting contamination and (2) clearing uncontaminated (or decontaminated) areas. Judgmental sampling provides for using the situational knowledge and experience of a field sampler in situations where probabilistic samples may not be necessary to detect contamination.

Standard statistical formulas for calculating the number of samples to achieve the desired confidence for a detection or clearance sampling goal assume that the overall FNR $=0$. In such situations, the number of samples is calculated to account for the uncertainty in the specific type of sampling approach being employed. However, the overall FNR is affected by anything in the sampling process that might yield a false negative, including (i) the RE of a sampling method (e.g., swab, wipe, or vacuum), (ii) the RE of storage or transportation steps, if applicable, (iii) the $\mathrm{RE}$ of the preparation and extraction step (i.e., extracting the contaminant from the sample media), and the uncertainty of the analytical/detection method and equipment. Hence, it is important to quantify the REs and uncertainties affecting the results of a method at each step in the process, so that the overall FNR can be determined. Current data indicates the REs and their uncertainties, and hence the overall FNR, may depend on the level of BA contamination. Hence, chamber and controlled studies need to investigate the performance of the various steps of the sampling process for a range of BA (or simulant) contamination levels. Additionally, standard formulas for calculating the number of samples necessary to achieve the desired confidence for a detection or clearance sampling goal can be extended to address situations where the overall FNR > 0. The Visual Sample Plan (VSP) software generally implements "standard" formulas to calculate the numbers of samples to address cases where the overall FNR $=0$. For some sampling approaches, it also implements extended formulas to address cases where the overall FNR $>$ 0. The PNNL "Statistics for Validated Sampling" project supporting the VSPWG will work with the VSP development team to develop extended formulas for calculating the number of samples required in other sampling situations when FNR $>0$. NIST will work with PNNL on this longer-term effort.

\section{Framework for Sampling}

Price et al. (2009) present a framework for investigating the "risk of contracting anthrax, the surface concentration of BA, the probability of detection, and the number of samples needed to ensure detection with a given degree of certainty". The framework includes a nomogram (Figure 3 in Price et al. 2009, presented here as Figure 1), consisting of a connected set of four graphs relating (1) risk to spores in air, (2) spores in air to spores on surfaces, (3) spores on surfaces to probability of detection, and (4) probability of detection to number of samples needed. These graphs respectively include curves for (1) low and high risk per dose, (2) low and high resuspension rate, (3) "best" (lab) and "field" performance, and (4) two confidence levels in detecting at least one positive sample. The two curves per graph are intended to illustrate that there are a range of possible relationships between variables in the graphs, and that realistic or

\footnotetext{
(a) Validated Sampling Plan Working Group. July 2009. Environmental Sampling Strategy for Bacillus anthracis During Crisis and Consequence Management, Edition 1 (draft), file dated October 22, 2009.
} 


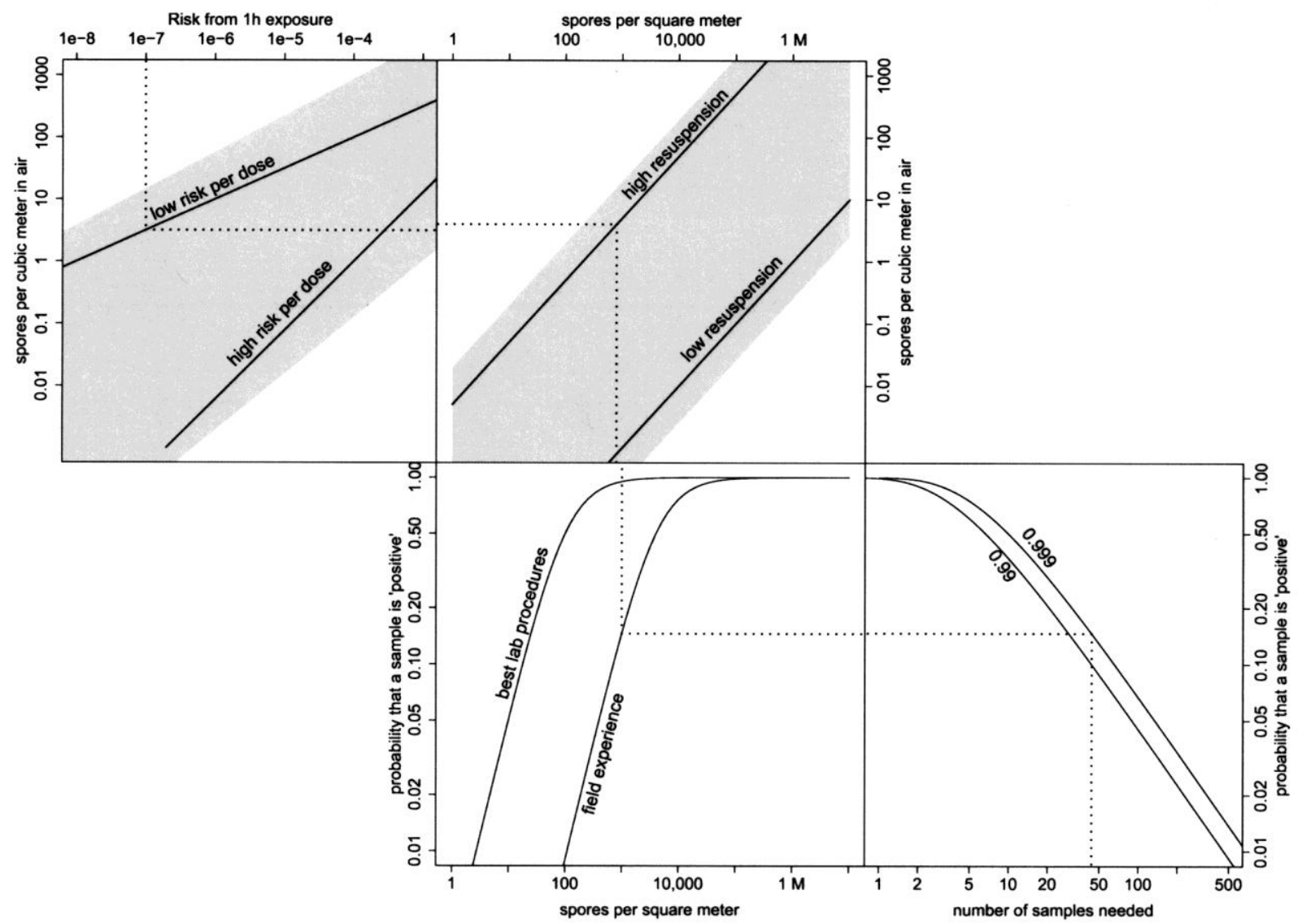

FIGURE 3. Determine the number of samples needed to ensure occupant safety: begin in the upper left portion of the figure by selecting an acceptable risk of infection for a person who will occupy the region for one hour. Read downward to a dose-response curve, then horizontally to the right to a "resuspension" curve. Continue downward into the plot below to a sampling effectiveness curve. Finally, read over to the plot at the bottom right, to a curve corresponding to probability of 0.99 or 0.999 of obtaining at least one positive sample. Read downward to the resulting $x$-value to determine the number of samples needed (all of them negative) to attain the selected risk level. The dotted line on the figure shows an example.

\section{Figure 1. Nomogram from Figure 3 of Price et al. (2009) Illustrating a Framework for Relating Risk to Numbers of Samples}

even conservative relationships should be used in evaluating risk due to Bacillus anthracis exposure and developing sampling plans. The nomogram is designed to select a risk value, and draw lines intersecting the relevant curve in each graph, ultimately leading to the desired probability that a sample is positive and the number of samples necessary to detect contamination with a desired confidence. We haven't fully studied (and hence are not endorsing) the specifics and underlying methods used by Price et al. (2009). However, we do find value in the presented framework for connecting risk, concentrations, probability of detection, and number of samples needed to make a detection or clearance decision with specified confidence. The last two steps of this framework are directly relevant to the analysis presented in this report.

Note that the "probability of detecting a positive sample" plays an important role in the framework of Price et al. (2009). The probability of detecting a positive sample is equivalent to 
the overall FNR discussed in Section 1. The probability of a false negative is just one minus the probability of correctly detecting a positive sample. Further, the overall RE of a sampling process (i.e., sampling method, preparation/extraction, storage/transportation, and analytical detection method) contributes to determining the overall FNR. Hence, developing the methodology and data to determine the overall RE and FNR for swab, wipe, and vacuum samples at various levels of contamination plays a key role in the overall framework for developing sampling strategies and plans. PNNL and NIST have proposed work over FY09FY11 to develop the methodology for calculating the overall RE and FNR using existing data and any new data that may be required. The summary of existing performance data from previous chamber and controlled studies is the first step in the formal project that will result in the ability to calculate the overall RE and FNR based on defined field and laboratory process information for a given scenario. PNNL and NIST developed this report to summarize existing data to identify situations where additional data may be needed to aide in VSPWG planning activities.

\section{Summary of Previous Chamber and Controlled Anthrax-Related Studies}

Previous chamber and controlled studies and their results using swab, wipe, and vacuum sampling methods to collect Bacillus anthracis (or simulant) contamination are summarized in a separate Excel file ["Summary of Anthrax Chamber and Controlled Studies, PNL-SA-69338 (PNNL 2009-11-04).xls"]. We focused on chamber and controlled studies because they provide a basis for estimating actual contamination levels, and using those values to estimate REs for defined steps of the sampling process. Only studies presenting data in terms of culture results are summarized in the Excel file to focus the effort. Results from polymerase chain reaction (PCR) analyses were not included because PCR is not yet routinely recommended as an approved procedure.

The studies included in the Excel summaries are from a bibliography that was vetted by the VSPWG prior to the start of this activity. The following publications were included in the analysis: Almeida et al. (2008), Brown et al. (2007a), Brown et al. (2007b), Brown et al. (2007c), Buttner et al. (2001), Buttner et al. (2004a), Buttner (2004b), CDC (2008) ${ }^{(a)}$, Edmonds et al. (2009), Einfeld et al. (2008), Estill et al. (2009), Frawley et al. (2008), Hodges et al. (2008), Nellen et al. (2006), Quizon et al. (2007), Rose et al. (2004), and Valentine et al. (2008). Additional publications that were excluded from the analysis due to lack of relevance to this work, are listed in the bibliography contained in Appendix A. The work performed here was limited to BA contamination and simulants for BA. Publications that did not address BA or simulants thereof were excluded from this analysis. Other publications were excluded because the work was not performed in a chamber or controlled study (which was considered important as a basis for ground truth estimation, estimating REs, and validation). Still others do not involve sampling (were limited to lab extraction procedures) or utilized sampling methods other than swab, wipe, or vacuum.

(a) Draft paper provided by Dr. Steven Morse of CDC. 
The characteristics and results of a given study included in the Excel file are summarized in several groups of columns (separated by heavier line borders). Different studies are represented by groups of rows, with each row corresponding to different aspects or tests of a study.

The study characteristics and results in the columns of the Excel summary tables, organized by the groups of columns in the tables, are briefly described in Table 1. The groups of columns are broadly divided in Study Characteristics and Study Results. Study Results are further divided into the categories: Means and \%RSDs, Numbers of Runs and Samples, Study Results Mean and \%RSDs, Recovery Efficiency - Mean and \%RSDs, and LOD and Rates. The entries in each category are further described in Table 1.

We noticed many differences in the way the various studies did things, and it wasn't possible to document them all in the Excel file or this report. However, one important difference worth highlighting is that different studies did different things experimentally and in calculations to obtain the "actual" contamination values for calculating REs. These differences affect the RE values and their uncertainties.

\section{Observations from Summary of Previous Anthrax-Related Chamber and Controlled Studies}

Table 2 summarizes the Excel table results from the 17 publications that discuss previous chamber and controlled studies (listed in Section 3). These tables show that there were 14 publications discussing swab sampling, 9 discussing wipe sampling, and only 4 discussing vacuum sampling. The gray cells in Table 2 indicate study characteristic/study result combinations that were not addressed by the 17 publications. Lab-to-lab uncertainty and run-torun uncertainty were listed with study results and REs only by Estill et al. (2009). Because these sources of uncertainty are missing from most of the studies, the uncertainties reported can be expected to underestimate the total uncertainties in results.

Table 2 also shows that few of the studies had results available from varying the following factors:

1) type (characteristics) of the sampling media,

2) wetting agent for the sampling media (swab and wipe),

3) nature of the contaminant,

4) contaminate deposition,

5) storage/transportation, and

6) preparation/extraction.

In particular, there was very limited investigation of storage and transportation effects. Some of these factors were varied across the different studies. However, multiple differences between studies complicate using the data to investigate the effects of the factors (e.g., on RE) varied across and within studies. 
Table 1. Descriptions of Columns in Excel Summary Tables

\begin{tabular}{|c|c|}
\hline \multicolumn{2}{|l|}{ Study Characteristics } \\
\hline Row Number & Continuous number to aid in referring to specific rows of a table. \\
\hline Study & Publication used to summarize the study \\
\hline Test \# & $\begin{array}{l}\text { A number of the form } x . y \text { where } x \text { is } 1,2,3, \ldots \text { for each study, and } y=1,2,3, \ldots \text { for } \\
\text { the tests within a study }\end{array}$ \\
\hline $\begin{array}{l}\text { Swab/Wipe/Vacuum } \\
\text { Characteristics }\end{array}$ & Characteristics or material of sampling method \\
\hline Wetting Agent & Liquid, if any, used to wet or pre-moisten the sampling material (e.g., swab or wipe) \\
\hline Surface Tested & Material type of surface sampled \\
\hline Nature of Contaminant & B. anthracis or related simulant \\
\hline Contaminant Amount & Amount or concentration of contaminant \\
\hline Contaminant Deposition & How contaminant was deposited on the test materials \\
\hline Transport / Storage Conditions & Transportation or storage conditions for samples before analysis \\
\hline Preparation/Extraction Method & Method used to prepare a sample and extract the contaminant \\
\hline Analytical Method & Method used to analyze prepared samples \\
\hline \multicolumn{2}{|l|}{ Study Results } \\
\hline \multicolumn{2}{|r|}{ Study Results - Mean and SDs } \\
\hline \# Test Runs & $\begin{array}{l}\text { The number of test runs (set up and performed separately at different times). These } \\
\text { may be thought of as "blocks" in statistical experimental design terminology. }\end{array}$ \\
\hline Total \# Test Samples & $\begin{array}{l}\text { Total number of samples used to calculate mean and standard deviations, as well as } \\
\text { recovery efficiency. }\end{array}$ \\
\hline Mean $\left(\mathrm{CFU} / \mathrm{cm}^{2}\right)$ & Average contamination over the number of samples \\
\hline Lab \%RSD & $\begin{array}{l}\text { Lab-to-lab percent relative standard deviation, which includes the variation from } \\
\text { preparing the samples, extraction, and analysis. }\end{array}$ \\
\hline Run \%RSD & $\begin{array}{l}\text { Percent relative standard deviation from replicate runs of a test performed at } \\
\text { different times. }\end{array}$ \\
\hline Sample Within Run \%RSD & $\begin{array}{l}\text { Percent relative standard deviation from replicate tests performed at the same time } \\
\text { (in one run) }\end{array}$ \\
\hline Within Sample \%RSD & $\begin{array}{l}\text { Percent relative standard deviation from split preparations and/or analyses from a } \\
\text { given sample }\end{array}$ \\
\hline Total \%RSD & $\begin{array}{l}\text { Total percent relative standard deviation including all of the preceding sources of } \\
\text { variation }\end{array}$ \\
\hline \multicolumn{2}{|r|}{ Recovery Efficiency (RE) - Mean and \% RSDs } \\
\hline RE Mean (\%) & Mean recovery efficiency over the number of test samples \\
\hline RE Lab \%RSD & Lab-to-lab percent relative standard deviation of RE \\
\hline RE Run \%RSD & Run percent relative standard deviation of RE \\
\hline RE Sample Within Run \%RSD & Sample-within-run percent relative standard deviation of RE \\
\hline RE Total \%RSD & Total percent relative standard deviation of RE \\
\hline \multicolumn{2}{|r|}{ LOD $\left(\right.$ CFU $\left./ \mathrm{cm}^{2}\right) \&$ Rates } \\
\hline Definition of LOD & How the limit of detection (LOD) is defined \\
\hline \# of Data Points & Number of data points used to calculate the LOD \\
\hline Positive Result Definition (CFU) & How a positive result (detection) is defined (e.g., $C F U \geq 1$ ) \\
\hline $\mathrm{LOD}\left(\mathrm{CFU} / \mathrm{cm}^{2}\right)$ & Value of the limit of detection \\
\hline LOD SD or $95 \% \mathrm{CI}\left(\mathrm{CFU} / \mathrm{cm}^{2}\right)$ & Standard deviation or $95 \%$ confidence interval for the LOD \\
\hline $\begin{array}{l}\text { Probability Curve for Detecting a } \\
\text { Positive }\end{array}$ & Method used to develop a probability curve for correctly detecting contamination \\
\hline False Negative Rate & $\begin{array}{l}\text { False negative rate based on controlled tests where the sampled surface was known } \\
\text { to be contaminated but yielded a negative result }\end{array}$ \\
\hline False Positive Rate & $\begin{array}{l}\text { False positive rate based on controlled tests where the sampled surface was known to } \\
\text { be uncontaminated but yielded a positive result }\end{array}$ \\
\hline Comments & Explanatory comments about the study or results \\
\hline
\end{tabular}


Table 2. Numbers of Studies with Various Results in the Excel Summary Tables

\begin{tabular}{|c|c|c|c|c|c|c|c|c|c|c|c|c|c|c|c|c|c|c|}
\hline \multirow[b]{3}{*}{ Number of Studies that Varied the ... } & \multicolumn{6}{|c|}{ Swabs (14) ${ }^{(\mathbf{a})}$} & \multicolumn{6}{|c|}{ Wipes (9) ${ }^{(\mathbf{a})}$} & \multicolumn{6}{|c|}{ Vacuums (4) ${ }^{(a)}$} \\
\hline & \multicolumn{2}{|c|}{$\operatorname{Res}^{(b)}$} & \multicolumn{2}{|c|}{$\mathrm{RE}^{(\mathrm{c})}$} & \multirow[b]{2}{*}{ 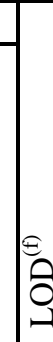 } & \multirow[b]{2}{*}{$\frac{\sqrt{00}}{\frac{00}{2}}$} & \multicolumn{2}{|c|}{$\operatorname{Res}^{(b)}$} & \multicolumn{2}{|c|}{$\mathrm{RE}^{(\mathrm{c})}$} & \multirow[b]{2}{*}{ ( } & \multirow[b]{2}{*}{ 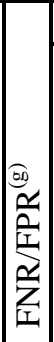 } & \multicolumn{2}{|c|}{$\operatorname{Res}^{(\mathrm{b})}$} & \multicolumn{2}{|c|}{$\mathrm{RE}^{(\mathrm{c})}$} & \multirow[b]{2}{*}{ 今ి } & \multirow[b]{2}{*}{ 䣝 } \\
\hline & 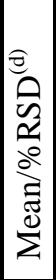 & 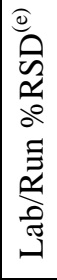 & 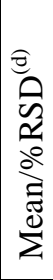 & 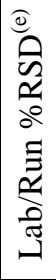 & & & 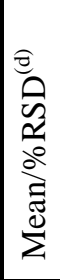 & 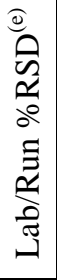 & 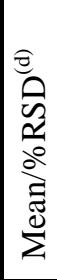 & 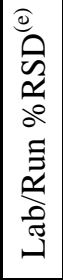 & & & 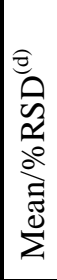 & 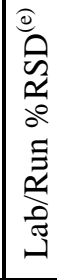 & 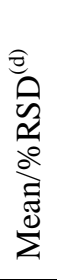 & 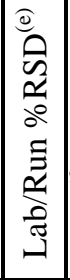 & & \\
\hline Type (characteristics) of the media & 3 & 0 & 6 & 0 & $\overline{0}$ & 0 & 1 & 0 & 1 & 0 & 0 & $\overline{0}$ & \multicolumn{6}{|c|}{0} \\
\hline Wetting agent & 0 & 0 & 2 & 0 & 0 & 0 & 3 & $\overline{0}$ & 1 & 0 & 1 & 0 & \multicolumn{6}{|c|}{ NA } \\
\hline Surface tested & 6 & 1 & 8 & 1 & 2 & 1 & 5 & 1 & 6 & 1 & 1 & 0 & 2 & 1 & 4 & 1 & & 1 \\
\hline Nature of contaminant & 1 & 0 & 1 & 0 & $\overline{0}$ & 0 & 1 & $\overline{0}$ & 0 & 0 & 0 & $\overline{0}$ & \multicolumn{6}{|c|}{0} \\
\hline Contaminant concentration & 3 & 1 & 7 & 1 & 2 & 3 & 1 & 1 & 2 & 1 & 1 & 1 & 1 & 1 & 2 & 1 & & 1 \\
\hline Contaminant deposition & 0 & 0 & 2 & 0 & 0 & 0 & 0 & $\overline{0}$ & 1 & 0 & 0 & 0 & \multicolumn{6}{|c|}{0} \\
\hline Transport / storage conditions ${ }^{(\mathrm{h})}$ & & \multicolumn{6}{|c|}{0} & \multicolumn{6}{|c|}{0} \\
\hline Preparation / extraction method & 1 & 0 & 3 & 0 & $\overline{0}$ & & 1 & $\overline{0}$ & 1 & 0 & 0 & $\overline{0}$ & & & 0 & & & \\
\hline
\end{tabular}

(a) Number in parentheses is the number of studies summarized.

(b) "Res" is a label for the study results (mean \& standard deviation or \%RSD, usually measured in CFU $/ \mathrm{cm}^{2}$ ).

(c) RE means the recovery efficiency results summarized from the study.

(d) Mean/\%RSD means that mean and within run \%RSD values were ascertained from the study.

(e) Lab/Run \%RSD means that the lab \%RSD and run \%RSD values were also ascertained from the study.

(f) LOD means that LOD values were available in the study.

(g) FNR/FPR means that false negative and/or false positive rates were available in the study.

(h) Storage results are available in Almeida et al. (2008), but sampling media were not part of the study.

Probability of detection, LOD, and FNR/FPR results are rarely reported in the publication results summarized in Table 2. As discussed in Section 2 of this report, the FNR (or equivalently, the probability of detecting a positive sample) and RE, each as a function of contaminant concentration, plays a key role in the framework for determining the number of samples necessary to achieve a detection or clearance goal with a specified confidence. Only a few of the studies in the Excel summary tables varied the BA (or simulant) contaminant at different concentrations. Of these studies, most investigated three or fewer levels of contaminant, with one study investigating six levels (Hodges et al. 2006). Of the studies that did investigate different levels of contaminant, only one (Estill et al. 2009) discussed developing a probability-of-detection curve as a function of contaminant concentration. Three other studies reported a LOD value, but did not discuss how it was calculated. We consider the lack of development of FNR (or probability of correct detection) and RE curves as functions of contaminant level to be a significant gap in all but one of the studies summarized. This raises the question of whether the original data could be obtained from the paper authors and the curves developed as part of future work. Developing these curves requires data at several contaminant concentration levels (at least 5-7, preferably), so studies with three or fewer concentration levels would not support such curve development. Further investigation would be needed to assess whether it would be possible to develop a probability of detection (or FNR) curves using the Hodges et al. (2006) data. 
The studies summarized in this report have large ranges of average RE values and their percent relative standard deviations ( $\% \mathrm{RSD} \mathrm{RE}_{\mathrm{RE}}$ ). For swabs, RE ranged from $0-49 \%$ and $\% \mathrm{RSD}_{\mathrm{RE}}$ ranged from $4-273$. For wipes, $\mathrm{RE}$ ranged from $1-86 \%$ and $\% \mathrm{RSD}_{\mathrm{RE}}$ ranged from $17-550$. For vacuums, RE ranged from $4-36 \%$ and $\% \mathrm{RSD}_{\mathrm{RE}}$ ranged from $27-233$. The $\%$ RSDs summarized above are from replicate tests performed at the same time, generally by the same samplers and same laboratory personnel. Hence, they do not include all relevant sources of variation, and can be expected to underestimate the total uncertainty.

The RE and \%RSD results summarized in the preceding paragraph exclude the results from Edmonds et al. (2009). They used four different kinds of swabs to sample several surface materials with liquid or dry aerosol deposited contamination. They reported average RE values ranging from $42-93 \%$ and $\% \mathrm{RSD}_{\mathrm{RE}}$ values ranging from $8-29$. These levels of performance are noticeably better than in the other studies for swabs. The likely reason for the improved performance observed by Edmonds et al. (2009) is the higher surface concentration of contaminant used in their study. This re-emphasizes the need to quantify the performance of sampling methods at several contaminant concentrations.

The wide range of RE values across the studies is a result of the impacts of several factors varied within and across the studies (e.g., concentration of contaminant; method of deposition; materials and specifics of swabs, wipes, and vacuum socks; wetting agent for swabs and wipes; surface being sampled; and specifics of sample preparation and extraction methods). Hence, the

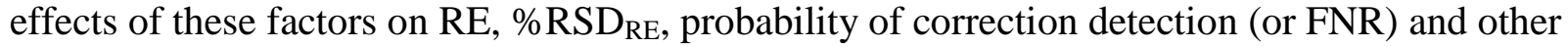
performance measures need to be quantified. It was beyond the scope of the current work to obtain and perform a statistical analysis of the data from all the studies summarized to quantify and assess the significance of factor effects on the performance measures. However, it will be necessary to quantify the effects of any factors that may vary in future BA contamination events, so as to provide the needed inputs for calculating the overall confidence and uncertainty in contamination detection and clearance decisions.

Several other observations from individual anthrax studies are discussed in the following bullets.

- The studies summarized in the Excel file generally (except for a few direct-inoculation tests) used one of two contaminant deposition methods (1) contaminant in liquid that was allowed to dry after deposition, and (2) dry aerosol. Two studies for swabs and one study for wipes reported REs while varying deposition method. No vacuum studies varied deposition method. Edmonds et al. (2009) found that REs differed significantly depending on liquid vs. dry deposition, with the difference depending on the sampling method.

- For directly inoculated petri dishes, Buttner et al. (2001) separately reported sampling loss and processing loss, as well as the overall RE, for two swab and one wipe sampling methods. For all three, the majority of the loss came in the processing step, not the sampling step. This result was confirmed by other studies:

○ Rose et al. (2004) found average REs of $84-94 \%$ for inoculated swabs made of different materials. They also found an average RE of $99.9 \%$ for inoculated stainless steel coupons run during the wipe tests. 
- Brown et al. (2007) found average REs for inoculated rayon swabs and inoculated polyester-rayon wipes of $76 \%$ and $93 \%$, respectively. They also found average REs of $99.9 \%$ and $99 \%$ for inoculated stainless steel coupons run during the swab and wipe tests, respectively.

○ Nellen et al. (2006) found average REs of 44.6 - 73.7\% when sampling with rayon swabs across five different surfaces. When adding the processing steps, the REs drop to $19.8-28.6 \%$. When sampling with cotton swabs the average RE was $66.1 \%$, with it dropping to $46.1 \%$ when the processing steps were included.

If similar results hold for swabs, wipes, and vacuum socks made of various materials, then the specifics of the preparation/extraction step (solution used, time, sonication and/or vortexing) would be very important in maximizing RE. The optimal processing conditions may depend on the sampling material used and the resuspension solution and methods of dissociation (vortexing, sonication). Several publications identified in the bibliography (Appendix A) provide insight into the individual processing steps and highlight the variability associated with the different lab processing procedures (Dauphin et al 2009, Dragon et al. 2001, Dewhurst et al. 1986, Jeng et al. 1990, and Puleo et al. 1967). These publications, as well as any additional publications that focus on the performance of the preparation/extraction step for given wipe, swab, or vacuum sock materials, would be useful to identify factors that impact the overall uncertainty analysis in an updated version of the Excel summary tables.

- Price et al. (2009) emphasize the importance of quantifying the performance of methods (e.g., sampling, extraction, storage/transportation, and analysis) under realistic conditions not just highly-sanitized laboratory conditions. This is because the performance (e.g., RE, uncertainties, FNR) may not be as good under realistic conditions as in highly-sanitized laboratory conditions. Only three studies (Buttner et al. 2001, Brown et al. 2007, Einfeld et al. 2008) report the results of tests with "interfering" material present (non-anthrax organism, silicon dioxide, and grime, respectively) in addition to the primary contaminant (Bacillus anthracis or simulant) studied.

- Turnbull et al. (2007) investigated the effects of temperature and time on activating over 50 strains of Bacillus anthracis spores suspended in water. Counts of viable spores before and after various heat treatments are summarized in Table 3 of Turnbull et al. (2007). All temperature and time combinations resulted in reduced counts more frequently than increased counts. Mean values of the ratio of heated/unheated results ranged from near 0 to 0.87. ${ }^{\text {(a) }}$ The authors concluded that activation temperatures should be kept to $\leq 70^{\circ} \mathrm{C}$ with holding times at such temperatures not needing to exceed 15-30 minutes.

Many other observations and findings could be made based on the studies summarized, but it was beyond the scope of this effort to complete detailed data analyses and assessments.

\footnotetext{
(a) This suggests that the heat treatment to "activate" spores tends to kill some spores more than activate them. This issue will need a decision made regarding whether to perform an "activation" step as part of processing for any future chamber/controlled study.
} 


\section{Recommendations for a Future Chamber or Controlled Study}

For the purposes of this report, a summary of previous chamber and controlled studies was developed and reported in the Excel file ["Summary of Anthrax Chamber and Controlled Studies, PNL-SA-69338 (PNNL 2009-11-04).xls"] Observations from this analysis described in Section 4 identified several gaps in the studies that need to be addressed in one or more future chamber or controlled studies.

The largest gap is the lack of information that supports developing relationships between performance of sampling methods [e.g., RE and FNR (or probability of correct detection)] and contaminant concentration. Such relationships are needed for combinations of (1) surface materials, (2) swab, wipe, and vacuum sample collection methods, (3) preparation/extraction methods, and (4) analytical methods that may occur in real anthrax contamination events. The focus of future studies should address the range of processing methods for sampling materials that have been historically utilized and determine what methods would be applied (including current LRN methods) in future anthrax contamination events.

A second large gap apparent from the literature summary is the lack of studies to investigate and quantify the effects of storage and transportation conditions on performance results (e.g., RE and FNR). Of the studies summarized in this report, only Almeida et al. (2008) investigated the effects of storage and transportation on performance results. However, that study did not investigate these effects with respect to sample collection, preparation/extraction, and analytical methods. Hence, the applicability and usefulness of that study's results is limited for BA contamination situations where a sampling and analysis process will be used to make detection and clearance decisions.

A third significant gap is that previous studies did not capture all of the sources of uncertainty affecting performance results. Many of the studies investigated only short-term, within-test uncertainties (repeatability), and did not investigate run-to-run or lab-to-lab uncertainties (reproducibility). Hence, the estimates of performance measure uncertainty reported in those studies can be expected to underestimate the total uncertainty. Further, in studies that did capture more than one source of uncertainty, the statistical measures of uncertainty reported may have been improperly calculated. ${ }^{\text {(a) }}$

These and other gaps discussed in Section 4 indicate that a new chamber or controlled study is needed. A chamber or controlled study (versus a large-scale facility study) is recommended because of the need for a defensible measure of the concentration of contaminant deposited on the surface (ground truth estimate) in order to accurately calculate the performance characteristics (e.g., RE, probability of correct detection, FNR) of the steps of the sampling and analysis process.

\footnotetext{
(a) A very common error is to calculate the standard deviation (or \% RSD) from a set of data subject to more than one source of uncertainty. The appropriate approach is to use a statistical variance-component-estimation method to separately estimate the standard deviation (or \% RSD) for each source of uncertainty, and then properly combine the separate estimates into an estimate of total uncertainty.
} 
We recommend that one or more new chamber or controlled studies be conducted to address the three primary focuses below, which are associated with the three significant gaps discussed previously.

1. Bacillus anthracis (or Simulant) Concentrations: A chamber or controlled study should be performed with at least five levels of Bacillus anthracis (or simulant) surface concentration per sampling method, with target goals for the probability of correct detection being $0.20,0.40,0.60,0.80$, and 1.00 . If six or seven levels are possible, additional goals of 0.90 and 0.70 , respectively, would provide for better estimation of the upper portion of probability-of-correct-detection (or FNR) curves. A preliminary screening study should be performed before the main study to investigate a range of Bacillus anthracis (or simulant) surface concentrations and identify levels at which the probability of detecting a positive sample takes the goal values. The contaminant concentration levels yielding these probabilities of correct detection may differ for the three different sampling methods (swab, wipe, vacuum) and other factors that may be varied in the study (discussed subsequently). Hence, it may be necessary to select more than five (e.g., 7 - 10) contaminant concentrations so that the range of $0.20-0.40-0.60$ 0.80-1.00 values are ultimately covered for various combinations of surface material, sampling method, preparation/extraction method, storage/transportation conditions, and analytical method.

2. Storage and Transportation: Multiple storage and/or transportation conditions need to be investigated to provide for quantifying the impacts ("recovery efficiencies") associated with such conditions. Storage and transportation conditions could be investigated as part of a new chamber or controlled study, where samples from the study would be subjected to the different conditions and sent to different laboratories. However, depending on the other factors investigated in the study (see subsequent discussion), this may make the study too large. Another option would be to study storage and transportation conditions in a "second" study where samples are inoculated, thus providing a better basis for separately quantifying effects of storage and transportation compared to the effects of sample-collection factors. Whether it is reasonable to perform a separate "second" study depends on whether there are interactive effects between storage and transportation factors and the factors investigated in the "first" study.

3. Uncertainty: A new chamber or controlled study should be designed to capture all applicable sources of uncertainty (reproducibility and repeatability) in the steps of the sampling process (i.e., sample collection, storage and transportation, preparation/extraction, and analytical). Tests in the study should be performed in at least three runs (possibly more depending on the number of within-run replicates that can be achieved). Runs should be performed in separate "blocks" of time. Ideally a run should include sampling, storage/transport, preparation/extraction, and analytical aspects. Using different personnel (e.g., samplers, laboratory) in each run would provide for capturing those reproducibility sources of uncertainty.

The following factors should be considered in developing the experimental design for a new chamber or controlled study to address the primary recommendations discussed above. These 
factors may influence the performance results of sampling methods/process, possibly via interactive effects with factors associated with the primary goals above.

(a) Bacillus anthracis (BA) versus Simulants: Previous chamber and controlled studies have used BA and various simulants of BA. However, these studies have not addressed the relationship between results with simulants and BA results. If it is not feasible to use BA in a new chamber or controlled study, then measurements of organism properties relevant to sampling and resuspension studies should be performed on BA and the various simulants. The data should then be used to establish the relationships for sampling performance results between BA and its simulants.

(b) Deposition Method: A chamber or controlled study could investigate sampling performance for relevant contaminant deposition methods (in liquid such as ethanol or water versus dry aerosol) while varying the other test conditions. Edmonds et al. (2009) investigated dry aerosol versus liquid deposition, but only at a high contaminant concentration. Including deposition method in a new chamber or controlled study would provide for quantifying how deposition method influences the results (e.g., RE, relationship between FNR and contaminant concentration), including interactions with other factors. It would also provide for comparing results with other deposition methods to those from CDC-validated methods that utilized ethanol deposition. If it is decided that dry aerosol deposition is the most likely to occur in real events and evaluation of sampling methods under conditions indicative of a real event is the goal of the study, a new chamber or controlled study could focus solely on aerosol deposition.

(c) Interfering Material in Addition to Primary Contaminant: Three studies (Buttner et al. 2001, Brown et al. 2007, Einfeld et al. 2008) investigated the effects of interfering material (e.g., grime or a non-anthrax organism) and found they can have a significant effect on RE. However, none of those studies looked at FNR as a function of contaminant concentration or LOD. A chamber or controlled study could be performed with one or more interfering materials, and with three levels of each material: 1) no interfering material, 2) low level of interfering material, and 3) high level of interfering material.

(d) Surface Types: Surface types with sampling properties that span those of surfaces which may be encountered in the real world should be investigated in a new chamber or controlled study. These may include some or all of glass, stainless steel or other metal, vinyl, wood, painted wallboard, upholstery fabric, residential cut-pile carpet (thicker), commercial loop carpet (thinner), and possibly others (including aged or dirty carpets, upholstery fabric, etc). Care should be taken to use ASTM grade materials where possible (aluminum, stainless steel, glass, and polymer materials) to reduce some variability in material composition and provide a mechanism for comparison in follow-on studies. Although surface types appear to be well tested in previous studies, those studies did not develop LOD values or the relationship between FNR (or probability of correct detection), contaminant concentration, and other factors that affect these results. Further, testing various surface types while varying other factors will help identify factors that 
may have an interaction effect when paired with surface type. This has not been previously studied.

(e) Swab, Wipe, and Vacuum Sampling Methods: To vary other factors and perform enough runs and replicates to meet the primary goal of developing relationships for RE and FNR (or probability of correct detection) with contaminant concentration level, it may be necessary to limit the investigation to one or two sampling devices/materials/wetting agents for each sample collection method (swab, wipe, and vacuum). However, more combinations of sample materials and wetting agent combinations that may be used in the real world could be included if doing so would not make the chamber or controlled study too large.

(f) Preparation/Extraction Methods: As noted previously, the preparation/extraction step may be the primary contributor in determining RE (and FNR). If a standard or preferred preparation/extraction method could be selected, the chamber or controlled study could focus on that method. Otherwise, it may be very useful to identify the most promising small subset of the preparation/extraction methods investigated in other studies, and investigate them in a new, more comprehensive chamber or controlled study.

(g) Culture and Analytical: Different culture and counting methods were used in the studies summarized in the Excel tables. "Standard/approved" methods (e.g., LRN procedures) that may be used in Bacillus anthracis contamination events could be included as levels of a culture/analytical factor in a possible future chamber or controlled study.

(h) Reference Samples: A reference sample for determining RE should be closely co-located with each surface sample to be collected using swab, wipe, or vacuum methods. That way, the RE for each surface sample is calculated using the paired, co-located reference sample. This approach corrects for unavoidable variation in contaminant deposition in a chamber or controlled area, so that such differences do not inflate the uncertainties of RE. Other reference sample issues will also need to be considered in the experimental design of a new chamber or controlled study.

Several of these factors would clearly have to be varied in a new chamber or controlled study, so in that sense it may be misleading to list them secondarily to the three primary goals we list for the study. Appendix B briefly discusses other factors or aspects that were considered for inclusion in a possible future chamber or controlled study.

It is beyond the scope of this report to fully develop an experimental design for a possible future chamber or controlled study. However, a new chamber or controlled study that varied all of the factors mentioned previously may be too large to perform. Hence, it may be necessary in designing such a study to focus on fewer or fixed levels of some factors based on (1) methods that would be used in real Bacillus anthracis contamination events, and/or (2) results of previous studies. The choice of factors (and levels of those factors) to vary or fix in a new chamber or controlled study, and how much to rely on previous studies in making such decisions, will require inputs and discussion from VSPWG members. 


\section{Summary}

The decision on whether the VSPWG should conduct a new chamber or controlled study should be based on what is needed to satisfy the two main GAO concerns: 1) lack of validated methods, and 2) making high-confidence detection and clearance decisions. The GAO reports specifically mentioned the use of probabilistic sampling approaches with respect to making highconfidence detection and clearance decisions. Methodology and related data for quantifying the overall uncertainty and confidence associated with detection and clearance decisions is needed to address the GAO concerns. This methodology must account for the performance and uncertainties for relevant sampling approaches, sample collection methods, sample transportation and/or storage effects, sample preparation and extraction methods, and sample analysis methods.

The literature summarized in the Excel file and discussed in this report contains considerable data on the performance of swab, wipe, and vacuum surface-sampling methods for Bacillus anthracis (or simulant) contamination. However, that body of work does not provide for fully quantifying the overall performance of sampling methods covering the several steps in the sampling process (sample collection, transportation/storage, preparation/extraction, and analytical). Additional work is needed to quantify the biases (e.g., REs), probabilities of correct detection (or FNRs), and uncertainties associated with sample collection, transportation and storage, preparation/extraction, and analytical methods over a range of contamination concentrations for relevant surface materials sampled/extracted/analyzed by relevant methods. Further, all of the studies summarized for this report did not capture one or more applicable sources of uncertainty. Hence, data from those studies can be expected to underestimate uncertainties in the associated steps of the sampling process. Therefore, an additional chamber or controlled study must be conducted so as to gather data that fully represents all of the sources of uncertainty in steps of the sampling process.

In conclusion, data from one or more additional chamber or controlled studies will provide for calculating the overall uncertainty and confidence in contamination detection and clearance decisions based on swab, wipe, and vacuum samples of various surface materials at various levels of surface contamination. Such data will also serve as inputs to methodology and formulas to be developed in subsequent work, which will provide for calculating the numbers of samples required to achieve desired confidence levels for detection and clearance in anthrax contamination events.

\section{Acknowledgments}

We would like to acknowledge and thank the following people who provided draft papers, additional data, or additional information not included in the published versions of papers.

Jamie Almeida: For email response and calculations to support integration of data from Almeida et al. (2008).

Mark Buttner: For providing antilog versions of data and data analysis results associated with Buttner et al. (2001). 
Kenneth Cole: For providing the data associated with the paper Almeida et al. (2008). Unfortunately, it was not possible for this report to redo our calculations based on interpolating data from figures in the paper.

Cheryl Estill: For providing a draft copy of the Estill et al. (2009) paper prior to its completion, acceptance, and publication. Also, for several email responses to our questions about that paper. Specifically, she provided the following about what they would do differently if they did the study again.

"If we were to do this study again we would: 1) make the chamber out of steel (the Plexiglas absorbed the VHP and caused us to have a 4 day clean out period between runs); 2) add more very low runs to reduce the confidence interval of the LOD; 3) we have been criticized for only having one technician take the samples-- consider multiple technicians; 4) make sure that if there is a positive blank you have quick access to that information so that procedures could be changed to reduce these positive blanks; 5) add a very large sampling area for vacuum samples which would be more realistic; and 6) put steel and carpet samples in the same chamber for direct comparison."

Misty Hein: For providing additional data analysis results associated with the Estill et al. (2009) study, for compatibility with our summary Excel file.

Robert Knowlton: For making us aware of and providing the Einfeld et al. (2008) presentation.

Nancy Valentine: For an email response to our questions regarding Valentine et al. (2008) and other helpful input and feedback.

Finally, the lead authors whose work is summarized in the Excel file were invited to review the summaries of their studies, and provide any corrections, revisions, clarifications, or data as appropriate. Some lead authors did provide feedback or additional data, which is greatly appreciated.

\section{References}

Almeida, J. L., B. Harper, and K. D. Cole. 2008. “Bacillus anthracis Spore Suspensions: Determination of Stability and Comparison of Enumeration Techniques". Journal of Applied Microbiology 104:1442-1448.

Amidan, B. G., G. F. Piepel, B. D. Matzke, J. J. Filliben, and B. J. Jones. 2007. Experimental Design for the INL Sample Collection Operational Test, PNNL-17129, Pacific Northwest National Laboratory, Richland, WA.

Brown, G. S., R. G. Betty, J. E. Brockmann, D. A. Lucero, C. A. Souza, K. S. Walsh, R. M. Boucher, M. Tezak, M. C. Wilson, and T. Rudolph. 2007a. "Evaluation of a Wipe Surface Sample Method for Collection of Bacillus Spores from Nonporous Surfaces". Applied and Environmental Microbiology 73:706-710. 
Brown, G. S., R. G. Betty, J. E. Brockmann, D. A. Lucero, C. A. Souza, K. S. Walsh, R. M. Boucher, M. S. Tezak, M. C. Wilson, T. Rudolph, H. D. Lindquist, and K. F. Martinez. 2007b. "Evaluation of Rayon Swab Surface Sample Collection Method for Bacillus spores from Nonporous Surfaces". Journal of Applied Microbiology 103:1074-80.

Brown, G. S., Rita G. Betty, John E. Brockmann, Daniel A. Lucero, Caroline A. Souza, Kathryn S. Walsh, Raymond M. Boucher, Matthew S. Tezak, and M. C. Wilson. 2007c. "Evaluation of Vacuum Filter Sock Surface Sample Collection Method for Bacillus Spores from Porous and Non-porous Surfaces". Journal of Environmental Monitoring 9:666-671.

Buttner, M. P., P. Cruz-Perez, and L. D. Stetzenbach. 2001. "Enhanced Detection of SurfaceAssociated Bacteria in Indoor Environments by Quantitative PCR." Applied and Environmental Microbiology 67:2564-2570.

Buttner, M. P., P. Cruz, L. D. Stetzenbach, A. K. Klima-Comba, V. L. Stevens, and T. D. Cronin. 2004a. "Determination of the Efficacy of Two Building Decontamination Strategies by Surface Sampling with Culture and Quantitative PCR Analysis". Applied and Environmental Microbiology 70:4740-4747.

Buttner, M. P., P. Cruz, L. D. Stetzenbach, A. K. Klima-Comba, V. L. Stevens, and P. A. Emanuel. 2004b. "Evaluation of the Biological Sampling Kit (BiSKit) for Large-Area Surface Sampling”. Applied and Environmental Microbiology 70:7040-7045.

Edmonds, J. M., P. J. Collett, E. R. Valdes, E. W. Skowronski, G. J. Pellar, and P. A. Emanuel. 2009. "Surface Sampling of Spores in Dry-Deposition Aerosols". Applied and Environmental Microbiology 75:39-44.

Einfeld, W., G. Brown, J. E. Brockmann, R. M. Boucher, M. S. Tezak, M. C. Wilson, and P. M. Baca. 2008. "Sampling Efficiency Studies on Clean and Dirty Outdoor Surfaces Using a Surface-Modified Bacillus atrophaeus Surrogate". Sandia National Laboratory, Albuquerque, NM. (Presentation at $3^{\text {rd }}$ National Conference on Environmental Sampling and Detection for Bio-Threat Agents, December 2008).

Estill, C. F., P. A. Baron, J. K. Beard, M. J. Hein, L. D. Larsen, L. Rose, F. W. Schaefer III, J. Noble-Wang, L. Hodges, H. D. A. Lindquist, G. J. Deye, and M. J. Arduino. 2009. "Recovery Efficiency and Limit of Detection of Aerosolized Bacillus anthracis Sterne from Environmental Surface Samples". Applied and Environmental Microbiology 75:4297-4306.

Frawley, D. A., M. N. Samaan, R. L. Bull, J. M. Robertson, A. J. Mateczun, and P. C. B. Turnbull. 2008. "Recovery Efficiencies of Anthrax Spores and Ricin from Nonporous or Nonabsorbent and Porous or Absorbent Surfaces by a Variety of Sampling Methods". Journal of Forensic Sciences 53:1102-1107. 
Hodges, L. R., L. J. Rose, A. Peterson, J. Noble-Wang, and M. J. Arduino. 2006. "Evaluation of a Macrofoam Swab Protocol for the Recovery of Bacillus anthracis Spores from a Steel Surface”. Applied and Environmental Microbiology 72:4429-30.

Nellen, J., P. Rettberg, G. Horneck, and W. R. Streit. 2006. "Planetary Protection - Approaching Uncultivable Microorganisms". Advances in Space Research 38:1266-1270.

Piepel, G.F. and B.G. Amidan. 2010. Strawman on What Validation of Anthrax Sampling Methods Should Entail, PNNL-19654, Pacific Northwest National Laboratory, Richland, WA.

Piepel, G. F., B. G. Amidan, and B. D. Matzke. 2009. Experimental and Sampling Design for the INL-2 Sample Collection Operational Test, PNNL-18187, Pacific Northwest National Laboratory, Richland, WA.

Price, P. N., M. D. Sohn, K. S. H. Lacommare, and J. A. McWilliams. 2009. "Framework for Evaluating Anthrax Risk in Buildings". Environmental Science and Technology 43:1783-1787.

Quizon, R., J. Quizon, A. Proescher, C. Bare, B. Goodenow, M. Wagner, E. Van Gieson. 2007. Test and Evaluation of Surface Sampling Approaches Before and After Small-Scale FumigationBased Decontamination Events, NSTD-07-0592. Applied Physics Laboratory, National Security Technology Department, John Hopkins University, Laurel, MD.

Rose, L., B. Jensen, A. Peterson, S. N. Banerjee, and M. J. Arduino. 2004. "Swab Materials and Bacillus anthracis Spore Recovery from Nonporous Surfaces". Emerging Infectious Diseases 10:1023-1029.

Turnbull, P. C. B., D. A. Frawley, and R. L. Bull. 2007. "Heat Activation/Shock Temperatures for Bacillus anthracis Spores and the Issue of Spore Plate Counts Versus True Numbers of Spores”. Journal of Microbiological Methods 68:353-357.

Valentine, N. B., M. G. Butcher, Y. F. Su, K. H. Jarman, M. Matzke, B. J. Webb-Robertson, E. A. Panisko, B. A. B. Seiders, and K. L. Wahl. 2008. "Evaluation of Sampling Tools for Environmental Sampling of Bacterial Endospores from Porous and Nonporous Surfaces". Journal of Applied Microbiology 105:1107-1113. 


\section{APPENDIX A}

\section{Bibliography of Publications Reviewed But Not Relevant to Studies on Collecting, Transporting, Preparing, and Analyzing Bacillus anthracis (or Simulant) Samples}

The bibliography lists publications that were considered but did not involve chamber or controlled studies that focused on swab, wipe, and vacuum sampling of Bacillus anthracis (or simulant) contamination. The reason for excluding each reference is given.

\begin{tabular}{|c|c|}
\hline Reference & Reason Excluded \\
\hline $\begin{array}{l}\text { Almeida, J. L., L. Wang, J. B. Morrow, and K. D. Cole. 2006. "Requirements for } \\
\text { the Development of Bacillus anthracis Spore Reference Materials Used to Test } \\
\text { Detection Systems". Journal of Research of the National Institute of Standards } \\
\text { and Technology 111:205-217. }\end{array}$ & $\begin{array}{l}\text { Discusses detection } \\
\text { methods and } \\
\text { developing } \\
\text { reference materials }\end{array}$ \\
\hline $\begin{array}{l}\text { Angelotti, R., J. L. Wilson, W. Litsky, and W. G. Walter. 1964. "Comparative } \\
\text { Evaluation of the Cotton Swab and Rodac Methods for the Recovery of Bacillus } \\
\text { subtilis Spore Contamination from Stainless Steel Surfaces". Health Laboratory } \\
\text { Science 1:289-296. }\end{array}$ & $\begin{array}{l}\text { Would need to } \\
\text { evaluate against } \\
\text { performance of } \\
\text { modern methods }\end{array}$ \\
\hline $\begin{array}{l}\text { Baron, P. A., C. F. Estill, G. J. Deye, M. J. Hein, J. K. Beard, L. D. Larsen, and G. } \\
\text { E. 2008. "Development of an Aerosol System for Uniformly Depositing Bacillus } \\
\text { anthracis Spore Particles on Surfaces". Aerosol Science and Technology } \\
\text { 42(3):159-172. }\end{array}$ & $\begin{array}{l}\text { Not focused on } \\
\text { sampling }\end{array}$ \\
\hline $\begin{array}{l}\text { Beecher, D. J. 2006. "Forensic Application of Microbiological Culture Analysis to } \\
\text { Identify Mail Intentionally Contaminated with Bacillus anthracis Spores". Applied } \\
\text { and Environmental Microbiology 72:5304-5310. }\end{array}$ & $\begin{array}{l}\text { Summary of } \\
\text { findings for the } \\
2001 \text { congressional } \\
\text { mailing incidences }\end{array}$ \\
\hline $\begin{array}{l}\text { Budowle, B., S. E. Schutzer, J. P. Burans, D. J. Beecher, T. A. Cebula, R. } \\
\text { Chakraborty, W. T. Cobb, J. Fletcher, M. L. Hale, R. B. Harris, M. A. Heitkamp, } \\
\text { F. P. Keller, C. Kuske, J. E. LeClerc, B. L. Marrone, T. S. McKenna, S. A. Morse, } \\
\text { L. L. Rodriguez, N. B. Valentine, and J. Yadev. 2006. "Quality Sample Collection, } \\
\text { Handling, and Preservation for an Effective Microbial Forensics Program”. } \\
\text { Applied and Environmental Microbiology 72:6431-6438. }\end{array}$ & $\begin{array}{l}\text { Discusses many } \\
\text { topics, but no } \\
\text { results from } \\
\text { chamber or } \\
\text { controlled studies } \\
\text { are presented }\end{array}$ \\
\hline $\begin{array}{l}\text { Burton, N., S. Grinshpun, and T. Reponen. 2007. "The Effect of Filter Material on } \\
\text { Bioaerosol Collection of Bacillus subtilis Spores used as a Bacillus anthracis } \\
\text { Simulant". Journal of Environmental Monitoring 7:475-480. }\end{array}$ & Air sampling study \\
\hline $\begin{array}{l}\text { Buttner, M. P., P. Cruz, L. D. Stetzenbach, and T. Cronin. 2007. "Evaluation of } \\
\text { Two Surface Sampling Methods for Detection of Erwinia herbicola on a Variety } \\
\text { of Materials by Culture and Quantitative PCR". Applied and Environmental } \\
\text { Microbiology 73:3505-3510. }\end{array}$ & $\begin{array}{l}\text { Not Bacillus } \\
\text { anthracis or } \\
\text { simulant }\end{array}$ \\
\hline $\begin{array}{l}\text { Carlsen, T. M., D. H. MacQueen, and P. W. Krauter. 2001. Sampling } \\
\text { Requirements for Chemical and Biological Agent Decontamination Efficacy } \\
\text { Verification. UCRL-AR-143245. Lawrence Livermore National Laboratory, } \\
\text { Livermore, CA. }\end{array}$ & $\begin{array}{l}\text { Decontamination } \\
\text { procedures }\end{array}$ \\
\hline
\end{tabular}




\begin{tabular}{|c|c|}
\hline Reference & Reason Excluded \\
\hline $\begin{array}{l}\text { Centers for Disease Control and Prevention. 2001. Evaluation of Bacillus } \\
\text { anthracis Contamination Inside the Brentwood Mail Processing and } \\
\text { Distribution Center -- District of Columbia. Morbidity and Mortality } \\
\text { Weekly Report 50:1129-1133. }\end{array}$ & $\begin{array}{l}\text { Summarizes } \\
\text { sampling results } \\
\text { from Brentwood } \\
\text { Mail Processing and } \\
\text { Distribution Center. } \\
\text { Not a chamber or } \\
\text { controlled study. }\end{array}$ \\
\hline $\begin{array}{l}\text { Centers for Disease Control and Prevention (CDC). 2002. Comprehensive } \\
\text { Procedures for Collecting Environmental Samples for Culturing Bacillus } \\
\text { anthracis. Government Report. Atlanta, GA: Centers for Disease Control. } \\
\text { http://www.cdc.gov/niosh/unp-envsamp.html. }\end{array}$ & $\begin{array}{l}\text { Sampling } \\
\text { procedures. No } \\
\text { actual study } \\
\text { performed. }\end{array}$ \\
\hline $\begin{array}{l}\text { Ciarciaglini, G., P. J. Hill, K. Davies, P. J. McClure, D. Kilsby, M. H. Brown, and } \\
\text { P. J. Coote. 2000. Germination-Induced Bioluminescence, a Route to Determine } \\
\text { the Inhibitory Effect of a Combination Preservation Treatment on Bacterial } \\
\text { Spores. Applied and Environmental Microbiology 66:3735-3742. }\end{array}$ & $\begin{array}{l}\text { Comparison of } \\
\text { preservation } \\
\text { treatments }\end{array}$ \\
\hline $\begin{array}{l}\text { Computer Sciences Corporation, C. 2005. Standardized Analytical Methods for } \\
\text { Use During Homeland Security Events. EPA/600/R-04/126B, Rev. 2. United } \\
\text { States Environmental Protection Agency, Washington, DC. }\end{array}$ & $\begin{array}{l}\text { Listing and } \\
\text { description of } \\
\text { methods. No study } \\
\text { performed. }\end{array}$ \\
\hline $\begin{array}{l}\text { Craythorn, J., A. Barbour, J. M. Matsen, M. R. Britt, and R. A. Garibaldi. } 1980 . \\
\text { "Membrane Filter Contact Technique for Bacteriological Sampling of Moist } \\
\text { Surfaces". Journal of Clinical Microbiology 12:250-255. }\end{array}$ & $\begin{array}{l}\text { This paper contains } \\
\text { information on filter } \\
\text { material extraction } \\
\text { efficiency }\end{array}$ \\
\hline $\begin{array}{l}\text { Dauphin, L. A., B. D. Moser, and M. D. Bowen. 2009. "Evaluation of Five } \\
\text { Commercial Nucleic Acid Extraction Methods for Their Ability to Inactivate } \\
\text { Bacillus anthracis Spores and Comparison of DNA Yields from Spores and } \\
\text { Spiked Environmental Samples". Journal of Microbiology Methods 76:30-37. }\end{array}$ & $\begin{array}{l}\text { Focuses on DNA } \\
\text { extraction }\end{array}$ \\
\hline $\begin{array}{l}\text { Defence Research and Development Canada. 2007. Objectives Assessment of } \\
\text { Anthrax Letter Mitigation Protocols in an Open Office Environment, TR 2007- } \\
\text { 237, Defence Research and Development Canada. }\end{array}$ & $\begin{array}{l}\text { Investigated the } \\
\text { dispersal of Bacillus } \\
\text { atrophaeus spores } \\
\text { from opening a } \\
\text { letter in an office } \\
\text { setting. Five } \\
\text { response protocols } \\
\text { were evaluated for } \\
\text { efficacy in reducing } \\
\text { re-aerosolization } \\
\text { and the extent of } \\
\text { contamination. }\end{array}$ \\
\hline $\begin{array}{l}\text { Dewhurst, E., D. M. Rawson, and G. C. Steele. 1986. "The Use of a Model System } \\
\text { to Compare the Efficiency of Ultrasound and Agitation in the Recovery of Bacillus } \\
\text { subtilis Spores from Polymer Surfaces". Journal of Applied Microbiology 61:357- } \\
\text { 363. }\end{array}$ & $\begin{array}{l}\text { This paper provides } \\
\text { data on the } \\
\text { uncertainty of } \\
\text { extraction based on } \\
\text { physical } \\
\text { dissociation method } \\
\text { used across } 5 \text { test } \\
\text { surfaces. Not yet } \\
\text { evaluated for }\end{array}$ \\
\hline
\end{tabular}




\begin{tabular}{|c|c|}
\hline Reference & Reason Excluded \\
\hline & $\begin{array}{l}\text { inclusion in Excel } \\
\text { summary file. }\end{array}$ \\
\hline $\begin{array}{l}\text { Dragon, D. C. and R. P. Rennie. 2001. "Evaluation of Spore Extraction and } \\
\text { Purification Methods for Selective Recovery of Viable Bacillus anthracis Spores". } \\
\text { Letters in Applied Microbiology 33:100-105 }\end{array}$ & $\begin{array}{l}\text { This paper } \\
\text { compares spore } \\
\text { recovery mediums. } \\
\text { Not yet evaluated } \\
\text { for inclusion in } \\
\text { Excel summary file. }\end{array}$ \\
\hline $\begin{array}{l}\text { EU Commission, D. H. a. C. P., Health Threats Unit. 2006. Biological Incident } \\
\text { Response and Environmental Sampling: A European Guideline on Principles of } \\
\text { Field Investigation. }\end{array}$ & $\begin{array}{l}\text { General, not the } \\
\text { results of a chamber } \\
\text { or controlled study }\end{array}$ \\
\hline $\begin{array}{l}\text { Favero, M. S., J. J. McDade, J. A. Robertsen, R. K. Hoffman, and R. W. Edwards. } \\
\text { 1968. "Microbiological Sampling of Surfaces". Journal of Applied Microbiology } \\
\text { 31:336-343. }\end{array}$ & $\begin{array}{l}\text { Too old to be } \\
\text { relevant to modern } \\
\text { methods and } \\
\text { performance }\end{array}$ \\
\hline $\begin{array}{l}\text { Higgins, J. A., M. Cooper, L. Schroeder-Tucker, S. Black, D. Miller, J. S. Karns, } \\
\text { E. Manthey, R. Breeze, and M. L. Perdue. 2003. "A Field Investigation of Bacillus } \\
\text { anthracis Contamination of U.S. Department of Agriculture and Other Washington } \\
\text { D.C. Buildings During the Anthrax Attack of October 2001". Applied and } \\
\text { Environmental Microbiology 69:593-599. }\end{array}$ & $\begin{array}{l}\text { Summary of } \\
\text { findings for the } \\
2001 \\
\text { contaminations in } \\
\text { DC }\end{array}$ \\
\hline $\begin{array}{l}\text { Hill, P. J., L. Hall, D. A. Vinicombe, C. J. Soper, P. Setlow, W. M. Waites, S. } \\
\text { Denyer, and G. S. A. B. Stewart. 1994. "Bioluminescence and Spores as } \\
\text { Biological Indicators of Inimical Processes". Journal of Applied Bacteriology } \\
\text { Symposium Supplement 76: 129S - 134S. }\end{array}$ & $\begin{array}{l}\text { Comparison of real- } \\
\text { time microbial } \\
\text { assay methods }\end{array}$ \\
\hline $\begin{array}{l}\text { Hoffmaster, A. R., R. F. Meyer, M. P. Bowen, C. K. Marston, R. S. Weyant, G. A. } \\
\text { Barnett, J. J. Sejvar, J. J. Jernigan, B. A. Perkins, and T. Popovic. } 2002 . \\
\text { "Evaluation and Validation of a Real-Time Polymerase Chain Reaction Assay for } \\
\text { Rapid Identification of Bacillus anthracis". Emerging Infectious Diseases 8:1178- } \\
1182 .\end{array}$ & $\begin{array}{l}\text { Evaluation of many } \\
\text { B. anthracis isolates } \\
\text { to evaluate PCR } \\
\text { approach. Not } \\
\text { sampling related. }\end{array}$ \\
\hline $\begin{array}{l}\text { Jeng , D. K., L. I. Lin, and L. V. Hervey. 1990. "Importance of Ultrasonication } \\
\text { Conditions in Recovery of Microbial Contamination from Material Surfaces". } \\
\text { Journal of Applied Bacteriology 68:479-484. }\end{array}$ & $\begin{array}{l}\text { Compares } \\
\text { ultrasonic } \\
\text { procedures }\end{array}$ \\
\hline $\begin{array}{l}\text { Kennedy, E. R., T. J. Fischbach, R. Song, P. M. Eller, and S. A. Shulman. } 1995 . \\
\text { Guidelines for Air Sampling and Analytical Method Development and Evaluation. } \\
\text { DHHS (NIOSH) Publication No. 95-117. U.S. Department of Health and Human } \\
\text { Services, Cincinnati, OH. }\end{array}$ & $\begin{array}{l}\text { Method } \\
\text { development and } \\
\text { evaluation } \\
\text { guidelines. Not for } \\
\text { Bacillus anthracis } \\
\text { or simulant. }\end{array}$ \\
\hline $\begin{array}{l}\text { Kirschner, L. E., and J. R. Puleo. 1979. "Wipe-Rinse Technique for Quantitating } \\
\text { Microbial Contamination on Large Surfaces". Applied and Environmental } \\
\text { Microbiology 38:466-470. }\end{array}$ & $\begin{array}{l}\text { Not for Bacillus } \\
\text { anthracis or } \\
\text { simulant }\end{array}$ \\
\hline $\begin{array}{l}\text { Lee, J. and R. A. Deininger. 2004. "A Rapid Screening Method for the Detection } \\
\text { of Viable Spores in Powder Using Bioluminescence". Luminescence 19: 209-211. }\end{array}$ & $\begin{array}{l}\text { Nonstandard } \\
\text { method }\end{array}$ \\
\hline $\begin{array}{l}\text { Lehman, E. C., and M. D. Hoover. 2006. Assessment of State-of-the-Art } \\
\text { Environmental Sampling Methods for Priority Biological and Chemical Terrorist } \\
\text { Agents, Final Report for Contract No. 200-2000-08018, Task Order No. } 15 . \\
\text { Battelle, Columbus, OH. }\end{array}$ & $\begin{array}{l}\text { Literature review of } \\
\text { methods and } \\
\text { assessment of the } \\
\text { extent to which they } \\
\text { are validated. No } \\
\text { results from }\end{array}$ \\
\hline
\end{tabular}




\begin{tabular}{|c|c|}
\hline Reference & \begin{tabular}{|l|} 
Reason Excluded \\
\end{tabular} \\
\hline & $\begin{array}{l}\text { chamber or } \\
\text { controlled studies. }\end{array}$ \\
\hline $\begin{array}{l}\text { Lindquist, H. D. A., S. Harris, S. Lucas, M. Hartzel, D. Riner, P. Rochele, and R. } \\
\text { DeLeon. 2007. "Using Ultrafiltration to Concentrate and Detect Bacillus anthracis, } \\
\text { Bacillus atrophaeus subspecies globigii, and Cryptosporidium parvum in 100-liter } \\
\text { Water Samples". Journal of Microbiological Methods 70:484-492. }\end{array}$ & $\begin{array}{l}\text { Focused on } \\
\text { ultrafiltration to } \\
\text { concentrate } \\
\text { organisms }\end{array}$ \\
\hline $\begin{array}{l}\text { McDermott, H. J. 2004. "Surface Sampling Methods", Chapter 19, In Air } \\
\text { Monitoring for Toxic Exposures, Second Edition, John Wiley \& Sons, Inc. New } \\
\text { York. }\end{array}$ & $\begin{array}{l}\text { Descriptions of } \\
\text { sampling methods, } \\
\text { no performance } \\
\text { results }\end{array}$ \\
\hline $\begin{array}{l}\text { Morse, S. A., R. B. Kellogg, S. Perry, R. F. Meyer, D. Bray, D. Nichelson, and J. } \\
\text { M. Miller. 2003. "Detecting Biothreat Agents: The Laboratory Response } \\
\text { Network". ASM News 69:433-437. }\end{array}$ & $\begin{array}{l}\text { Describes LRN. } \\
\text { Contains no study } \\
\text { results. }\end{array}$ \\
\hline $\begin{array}{l}\text { NASA. NASA Standard Procedures for the Microbial Examination of Space } \\
\text { Hardware. NASA Procedures and Guidelines. NPG: 5340.1D (Final Draft). }\end{array}$ & $\begin{array}{l}\text { Procedures, not } \\
\text { results of chamber } \\
\text { or controlled study } \\
\text { sampling Bacillus } \\
\text { anthracis or } \\
\text { simulant }\end{array}$ \\
\hline $\begin{array}{l}\text { National Academy of Sciences. 2005. Reopening Public Facilities After a } \\
\text { Biological Attack: A Decision-Making Framework. The National Academies Press, } \\
\text { Washington, D.C. }\end{array}$ & $\begin{array}{l}\text { Framework, not } \\
\text { results of chamber } \\
\text { or controlled study } \\
\text { sampling Bacillus } \\
\text { anthracis or } \\
\text { simulant }\end{array}$ \\
\hline $\begin{array}{l}\text { Nicholson, W. L. and A. C. Schuerger. 2005. "Bacilus subtilis Spore Survival and } \\
\text { Expression of Germination-induced Bioluminescence after Prolonged Incubation } \\
\text { Under Simulated Mars Atmospheric Pressure and Composition: Implications for } \\
\text { Planetary Protection and Lithopanspermia". Astrobiology 5: 536-544. }\end{array}$ & $\begin{array}{l}\text { Not relevant to } \\
\text { Bacillus anthracis } \\
\text { sampling by swab, } \\
\text { wipe, or vacuum }\end{array}$ \\
\hline $\begin{array}{l}\text { Oathout, J. M. 1999. "Determining the Dynamic Efficiency of Cleanroom Wipers } \\
\text { for Removal of Liquids and Particles from Surfaces". Journal of the IEST 42:17- } \\
26 .\end{array}$ & $\begin{array}{l}\text { Not directly } \\
\text { relevant to Bacillus } \\
\text { anthracis sampling } \\
\text { by swab, wipe, or } \\
\text { vacuum }\end{array}$ \\
\hline $\begin{array}{l}\text { O'Connell, H., L. Rose, J. Noble-Wang, and M. Arduino. 2009. "Shipping } \\
\text { Integrity of Bacillus anthracis Swab Samples". Centers for Disease Control } \\
\text { and Prevention, Atlanta, Georgia. (Presented at 7th ASM Biodefense and } \\
\text { Emerging Diseases Research Meeting, Baltimore, MD) }\end{array}$ & $\begin{array}{l}\text { Only have abstract, } \\
\text { no paper or } \\
\text { technical report at } \\
\text { this time }\end{array}$ \\
\hline $\begin{array}{l}\text { Oxborrow, G. S., A. L. Roark, N. D. Fields, and J. R. Puleo. 1974. "Mathematical } \\
\text { Estimation of the Level of Microbial Contamination on Spacecraft Surfaces by } \\
\text { Volumetric Air Sampling". Applied Microbiology 27:706-712. }\end{array}$ & $\begin{array}{l}\text { Not relevant to } \\
\text { Bacillus anthracis } \\
\text { sampling by swab, } \\
\text { wipe, or vacuum }\end{array}$ \\
\hline $\begin{array}{l}\text { Panning, M., S. Kramme, N. Petersen, and C. Drosten. 2007. "High Throughput } \\
\text { Screening for Spores and Vegetative Forms of Pathogenic B. anthracis by an } \\
\text { Internally Controlled Real-time PCR Assay with Automated DNA Preparation". } \\
\text { Medical Microbiology and Immunology 196:41-50. }\end{array}$ & $\begin{array}{l}\text { Focuses on DNA } \\
\text { extraction and PCR }\end{array}$ \\
\hline
\end{tabular}




\begin{tabular}{|c|c|}
\hline Reference & Reason Excluded \\
\hline $\begin{array}{l}\text { Poletti, L., C. Pasquarella, M. Pitzurra, and A. Savino. 1999. "Comparative } \\
\text { Efficiency of Nitrocellulose Membranes versus RODAC Plates in Microbial } \\
\text { Sampling on Surfaces". Journal of Hospital Infection 41:195-201. }\end{array}$ & $\begin{array}{l}\text { Methods not } \\
\text { relevant and not for } \\
\text { Bacillus anthracis } \\
\text { or simulant. }\end{array}$ \\
\hline $\begin{array}{l}\text { Puleo, J. R., M. S. Favero, and N. J. Petersen. 1967. "Use of Ultrasonic Energy in } \\
\text { Assessing Microbial Contamination on Surfaces". Applied Microbiology 15:1345- } \\
\text { 1351. }\end{array}$ & $\begin{array}{l}\text { Older work. } \\
\text { Focused on } \\
\text { recovery from } \\
\text { surfaces rather than } \\
\text { from swab, wipe, or } \\
\text { vacuum samples. }\end{array}$ \\
\hline $\begin{array}{l}\text { Reponen, T., K. Willeke, V. Ulevicius, A. Reponen, and S. A. Grinshpun. } 1996 . \\
\text { "Effect of Relative Humidity on the Aerodynamic Diameter and Respiratory } \\
\text { Deposition of Fungal Spores". Atmospheric Environment 30:3967-3974. }\end{array}$ & $\begin{array}{l}\text { Not wipe, swab, or } \\
\text { vacuum sampling of } \\
\text { Bacillus anthracis } \\
\text { or simulant }\end{array}$ \\
\hline $\begin{array}{l}\text { Rule, A., J. Kesavan, K. J. Schwab, and T. J. Buckley. 2007. "Application of Flow } \\
\text { Cytometry for the Assessment of Preservation and Recovery Efficiency of } \\
\text { Bioaerosol Samplers Spiked with Pantoea agglomerans". Environmental Science } \\
\text { and Technology 41, 2467-2472 }\end{array}$ & $\begin{array}{l}\text { Air sampling, not } \\
\text { Bacillus anthracis } \\
\text { or simulant }\end{array}$ \\
\hline $\begin{array}{l}\text { Sanderson, W. T., M. J. Hein, L. Taylor, B. D. Curwin, G. M. Kinnes, T. A. Seitz, } \\
\text { T. Popovic, H. T. Holmes, M. E. Kellum, S. K. McAllister, D. N. Whaley, E. A. } \\
\text { Tupin, T. Walker, J. A. Freed, D. S. Small, B. Klusaritz, and J. H. Bridges. } 2002 . \\
\text { "Surface Sampling Methods for Bacillus anthracis Spore Contamination". } \\
\text { Emerging Infectious Diseases 8:1145-1151. }\end{array}$ & $\begin{array}{l}\text { Summarizes } \\
\text { sampling results } \\
\text { from Brentwood } \\
\text { Mail Processing and } \\
\text { Distribution Center. } \\
\text { Not a chamber or } \\
\text { controlled study. }\end{array}$ \\
\hline $\begin{array}{l}\text { Sanderson, W. T., R. R. Stoddard, A. S. Echt, C. A. Piacitelli, D. Kim, J. Horan, } \\
\text { M. M. Davies, R. E. McCleery, P. Muller, T. M. Schnorr, E. M. Ward, and T. R. } \\
\text { Hales. 2004. "Bacillus anthracis Contamination and Inhalational Anthrax in a Mail } \\
\text { Processing and Distribution Center". Journal of Applied Microbiology 96:1048- } \\
1056 .\end{array}$ & $\begin{array}{l}\text { Summarizes } \\
\text { sampling results } \\
\text { from Brentwood } \\
\text { mail distribution } \\
\text { center. Not a } \\
\text { chamber or } \\
\text { controlled study. }\end{array}$ \\
\hline $\begin{array}{l}\text { Schonwalder, A., R. Kehr, A. Wulf, and K. Smalla. 2002. "Wooden Boards } \\
\text { Affecting the Survival of Bacteria?". Holz als Roh- und Werkstoff 60:249-257. }\end{array}$ & $\begin{array}{l}\text { Not swab, wipe, or } \\
\text { vacuum sampling of } \\
\text { Bacillus anthracis } \\
\text { or simulant }\end{array}$ \\
\hline $\begin{array}{l}\text { Teshale E. H., J. Painter, G. A. Burr, P. Mead, S. V. Wright, L. F. Cseh, R. } \\
\text { Zabrocki, R. Collins, K. A. Kelley, J. L. Hadler, D. L. Swerdlow et al. } 2002 . \\
\text { "Environmental Sampling for Spores of Bacillus anthracis". Emerging Infectious } \\
\text { Diseases 8:1083-1087. }\end{array}$ & $\begin{array}{l}\text { Sampling at the } \\
\text { Connecticut mail } \\
\text { distribution center. } \\
\text { Not a chamber or } \\
\text { controlled study. }\end{array}$ \\
\hline $\begin{array}{l}\text { Thorne, P. S., N. Metwali1, E. Avol, and R. S. McConnell. 2005. "Surface } \\
\text { Sampling for Endotoxin Assessment Using Electrostatic Wiping Cloths". Annals } \\
\text { of Occupational Hygiene 5:401-406. }\end{array}$ & $\begin{array}{l}\text { Wipe surface } \\
\text { sampling of } \\
\text { endotoxin, not } \\
\text { Bacillus anthracis } \\
\text { or simulant }\end{array}$ \\
\hline $\begin{array}{l}\text { Van Tassell, R. L. 2002. Monitoring the Decontamination of Bacterial Spc } \\
\text { Using Fluorescent Viability Assays. Luna Innovations, Blacksburg, VA. }\end{array}$ & $\begin{array}{l}\text { Nonstandard } \\
\text { acceleration step } \\
\text { and fluorescent }\end{array}$ \\
\hline
\end{tabular}




\begin{tabular}{|l|l|}
\hline Reference & Reason Excluded \\
\hline & viability assays \\
\hline $\begin{array}{l}\text { Vogt, B.M. and J. H. Sorensen. 2002. How Clean is Safe? Improving the } \\
\text { Effectiveness of Decontamination of Structures and People Following Chemical } \\
\text { and Biological Incidents. ORNL/TM-2002/178, Oak Ridge National Laboratory, } \\
\text { Oak Ridge, TN. }\end{array}$ & $\begin{array}{l}\text { Various case studies } \\
\text { not relevant to } \\
\text { Bacillus anthracis } \\
\text { sampling via wipe, } \\
\text { swab, or vacuum }\end{array}$ \\
\hline $\begin{array}{l}\text { Whyte, W., W. Carson, and A. Hambreaus. 1989. "Methods for Calculating the } \\
\text { Efficiency of Bacterial Surface Sampling Techniques". Journal of Hospital } \\
\text { Infection 13:33-41. }\end{array}$ & $\begin{array}{l}\text { Too old for } \\
\text { relevance to current } \\
\text { methods. }\end{array}$ \\
\hline $\begin{array}{l}\text { Yamayoshi, T., H. Doi, and N. Tatsumi. 1984. "Surface Sampling Using a Single } \\
\text { Swab Method". Journal of Hospital Infection 5:386-390. }\end{array}$ & $\begin{array}{l}\text { Too old for } \\
\text { relevance to current } \\
\text { methods. }\end{array}$ \\
\hline $\begin{array}{l}\text { Yung, P. T., M. J. Kempt, and A. Ponce. 2005. "A Rapid Single Spore } \\
\text { Enumeration Assay". IEEE Xplore 1029:1-13. }\end{array}$ & $\begin{array}{l}\text { Study of Bacillus } \\
\text { atrophaeus } \\
\text { recovery using two } \\
\text { not-common assay } \\
\text { methods. }\end{array}$ \\
\hline
\end{tabular}




\section{APPENDIX B \\ Other Factors or Aspects that Were Considered for Inclusion in a Possible Future Chamber or Controlled Study}

The following factors or ideas were considered, but were discarded as inappropriate for investigation in a possible new chamber or controlled study.

Sampling approaches: Probabilistic vs. judgmental vs. hybrid sampling approaches don't come into play for a chamber or controlled study whose focus is quantifying efficiencies, FNRs, etc.

Compare judgment samples selected by multiple experts: This would provide a basis for assessing the "expert effect" in selecting judgmental sample locations. However, as noted in the previous item, this type of investigation is not best suited for a chamber or controlled study.

Fine grid/coarse grid: This idea involves sampling on a fine grid, so that subsets of samples from coarser grids could be considered to assess different sampling approaches and plans. However, grid sampling is not appropriate in a chamber or controlled study where concentrations on coupons or specific locations are controlled.

Evaluate composite sampling: Probabilistic and hybrid sampling plans can result in large numbers of samples to achieve the desired confidence in detection and clearance decisions. Composite sampling has been discussed as a way to reduce the numbers of samples and/or increase the likelihood of detecting contamination if it exists. CS was explored in a very limited fashion with judgmental samples in INL-2. However, many questions remain about using CS for probabilistic as well as judgmental samples. The CS approach would be expected to be particularly effective if the spatial contaminant pattern is fairly random, but what about in spotty or hotspot contamination situations? How many wipe/swab/vacuum samples can be composited and still get good recovery efficiency? Will CS spread the contamination (wiping a clean area with a dirty wipe)? If dusty/grimy uncontaminated areas are wiped/swabbed/vacuumed in the same CS as a contaminated area, does that decrease the likelihood of detection? How many individual areas (for wipes and vacuum) and individual swabs should make up a CS? How many CSs should be taken? How does CS compare to non-compositing approaches?

Although composite sampling is a very strong idea to reduce sampling and analytical costs, it may be in conflict with a chamber or controlled study focusing on trying to quantify sampling performance (e.g., recovery efficiencies, FNRs, uncertainties) as a function of contaminant concentration and other affecting factors. Hence, it seems best to investigate composite sampling in a separate study.

Different Release/Dispersal Mechanisms: Currently, tests to determine the confidence in the ability to detect localized contamination (hotspots) with probabilistic and judgmental sampling have not been performed. The VSPWG should discuss the relevance of potential dispersal mechanisms and determine if a set of chamber tests are needed to challenge sampling plans generated using current characterization and clearance sampling strategy protocols while 
accounting for different potential release and dispersal mechanisms (e.g., hotspots, letter, fomites, and person-to-person contact).

However, this idea may not be compatible in a chamber or controlled study where the focus is quantifying REs, FNR, etc. on a per sample basis. The performance of a given sampling method may depend on the size of the contaminated area sampled, so there could be compatibility of the test goals, but such a study would have an increased number of test factors compared to those listed as options in Section 5.

In summary, the preceding ideas are not proposed for inclusion in a new chamber or controlled experimental study. However, a separate study of composite sampling may be extremely worthwhile. 